\title{
Responsibilities of The Church Steward in the Light of The Canons of Pseudo-Athanasius*
}

$T$ he Canons of Pseudo-Athanasius is a work of moralistic character ${ }^{1}$. In particular, it discusses the responsibilities of the clergy and provides guidelines for the management of ecclesiastical property. According to scholars who deal with the history of the Church in Egypt, this source text provides valuable information from the early period of development of local ecclesiastical institutions there ${ }^{2}$. The current division into one hundred and seven canons was introduced by Bishop Tannis, who wrote about this in his closing note. It seems that it was him who translated The Canons of Pseudo-Athanasius from Coptic into $\mathrm{Arabic}^{3}$. In any case, the Arabic version is the only one that has been

\footnotetext{
* The present paper is based on research made possible by the doctoral stipend Etiuda 4, awarded by the National Science Centre, Poland (decision no. DEC-2016/20/T/HS3/00414).

${ }^{1}$ The Canons of Athanasius of Alexandria, ed. W. Riedel, W. Crum, London 1904 (cetera: Can. Ps. Athan.). In 1920, Henri Munier published the Coptic fragments of The Canons of Pseudo-Athanasius that belonged to the private collection of Edwyn Hoskyns, cf. H. Munier, Mélanges de litterature copte, ASAE 19, 1920, p. 238-241. More on the latest findings on surviving Coptic fragments cf. A. Suciu, Notes on the Canons of Pseudo-Athanasius, https://alinsuciu.com/2011/07/02/noteson-the-canons-of-pseudo-athanasius/.

${ }^{2}$ Cf. E. Wipszycka, Le Istituzioni Ecclesiastiche in Egitto, [in:] L'Egitto Cristiano aspetti e problemi in eta Tardo-Antica, ed. A. Camplani, Roma 1997 [= SEA, 56] p. 225-226.

${ }^{3}$ We know very little about Bishop Michael of Tannis. Wilhem Riedel (Introduction, [in:] The Canons of Athanasius..., p. IX) states that Michael was made deacon during the pontificate of Patriarch Zachariah (1004-1032), priest during the ministry of Shenya II (1032-1047), and appointed Bishop of Tannis by Patriarch Christodolos (1047-1077). The problem is that Riedel took his information from a monograph by an $18^{\text {th }}$ century researcher, Eusèbe Renaudot (Historia Patriarchum Alexandrinorum Jacobitarum ad Marco usque ad finem saeculi XIII, Paris 1713, p. 414), who, in turn, based his conclusions on Coptic traditions that we cannot verify. It is certain, however, that Michael continued to write a compilation work entitled The History of Patriarchs of Alexandria. In his fifth volume he described events up to 1046. Cf. J. DEN Heijer, History of the Patriarchs of Alexandria, [in:] The Coptic Encyclopedia, vol. IV, ed. A.S. Atrya, New York 1991, p. 1239-1242. Tannis or Tinnis is a city in the eastern part of the Nile delta, cf. R. Stewart, Tinnis, [in:] The Coptic Encyclopedia..., vol. VII, p. 2269.
} 
preserved in its entirety to this day. Researchers are convinced that the original was written in Greek. According to Walter Crum, the oldest fragments, preserved in the Sahidian dialect, date back to the turn of the sixth and seventh centuries ${ }^{4}$. The Arabic translation was made in the $11^{\text {th }}$ century at the earliest, if it was indeed done by the aforementioned Bishop of Tannis. ${ }^{5}$. It is impossible to establish when the Greek original was written. David Brakke believes that it happened shortly after Athanasius's death ${ }^{6}$. Annick Martin and Ewa Wipszycka agree with his view ${ }^{7}$. A very important indication when dating The Canons of Pseudo-Athanasius is the fact that the author does not mention Christmas among Christian holidays. This led scholars to hypothesize that the work must therefore have been written before 432, when the holiday was first celebrated in Egypt ${ }^{8}$.

The question of authorship is yet to be solved. Wilhelm Riedel and Walter Crum were inclined to believe that, according to the notes in the introduction and in the conclusion, the author was indeed Bishop Athanasius of Alexandria9. Contemporary scholars, however, consider that assertion highly unlikely. Indeed, it would appear that Ewa Wipszycka is right in stating that there are no indications that The Canons of Pseudo-Athanasius were of Alexandrian provenance ${ }^{10}$. I, too, believe there is no evidence of the centralist views of the Bishop of Alexandria in this work. The writer does not require the bishop to participate in synods. When discussing specific aspects of Easter, he does not refer to the guidelines that would be contained in the current Passover letter. Significantly, he does not expect the bishop to be loyal to the patriarch of Alexandria. Moreover, Ewa Wipszycka pointed out one more very important aspect, namely that this work is not mentioned anywhere in the rather well preserved Greek pastoral legacy

\footnotetext{
${ }^{4}$ W. RiedeL, Introduction..., p. X.

${ }^{5}$ René G. Coquin (Canons of Pseudo-Athanasius, [in:] The Coptic Encyclopedia..., vol. II, p. 458-459) noted that there was no Arabic translation of The Canons of Pseudo-Athanasius in Nomocanon of Patriarch Gabriel ibn Turayk (1131-1145), the collection of Safi ibn al-Assal (13 ${ }^{\text {th }}$ century) and other collections from the $13^{\text {th }}$ and $14^{\text {th }}$ centuries. In my opinion, however, this does not mean necessarily that Arabic translation was produced later. It was probably not so widespread. It did not appear until the $14^{\text {th }}$ century on the list of Abu al-Barakat ibn-Kabar. We do not know whether Egyptian Christians were still using The Canons of Pseudo-Athanasius at the time or whether the text was completely forgotten by then. After all, the Copts were likely to have continued to use copies in the Sahidian dialect during this time.

${ }^{6}$ D. BRAKke, Canon Formation and Social Conflict in Fourth-Century Egypt: Athanasius of Alexandria's Thirty-Ninth Festal Letter, HTR 87.4, 1994, p. 412.

${ }^{7}$ A. Martin, Athanase d'Alexandrie et l'Église d'Égypte au IVe siecle (328-373), Rome 1996, p. 657; E. WipszycKa, Études sur le Christianisme dans l'Egypte de l'antiquite tardive, Roma 1996 [= SEA, 52], p. 205.

${ }^{8}$ R.G. Coquin, Canons of Pseudo-Athanasius..., p. 458; A. Martin, Athanase d'Alexandrie..., p. 176-177, n. 237; E. Wipszycka, The Alexandrian Church. People and Institutions, Warsaw 2015 [= JJP. Supplement, 25], p. 30.

${ }^{9} \mathrm{~W}$. RiEdEL, Introduction..., p. XIV.

${ }^{10}$ Cf. E. Wipszycka, The Alexandrian Church..., p. 275.
} 
of Athanasius. The researcher has been right to conclude that it is easier for us to explain the attribution of this work to Athanasius than to explain how it might have been forgotten ${ }^{11}$. Also important is the question of the writing style, which the Polish scholar considered to be "not of high standard". Although the author often refers to specific books of the Bible, especially to the Old Testament, he does not do so in the style of Athanasius, who was known for his extensive theological figures, lengthy moralistic passages and often authoritative and uncompromising tone $^{12}$. Researchers of Egyptian ascetism noticed some similarities between the writings of Athanasius, which he addressed to women and The Canons ${ }^{13}$. However, this is insufficient basis to draw any definitive conclusions ${ }^{14}$. We are unable to establish whether the information about Athanasius's authorship appeared in the Greek original or whether it was included only in the Arabic translation ${ }^{15}$. It can be inferred that its placement as well as the reference to the writings of Athanasius was a deliberate action aimed at lending credibility to his authorship. At present, scholars believe that this work was written by a bishop of one of the provincial Egyptian cities ${ }^{16}$. We do not know how large was the area it covered but I have no doubt that it was one of many Hellenized mêtropoleis ${ }^{17}$. The distance between them and Alexandria, especially the Patriarch's seat, must have allowed the author

\footnotetext{
${ }^{11}$ Ibidem, p. 30.

${ }^{12}$ More on Athanasius's unique writing style cf. D. Schmidtz, Schimpfwörter in Athanasius' Rede gegen die Arianer, [in:] Roma Renascens. Beiträge zur Spätantike und Rezeptionsgeschichte - Ilona Opelt von Ihren Freunden und Schülern zum 9.7.1988 in Verehrung gewidmet, ed. M. WissemanN, Frankfurt-Paris 1988, p. 308-320; K. Anatolios, Athanasius. The Coherence of His Thought, London-New York 2004, p. 190, 191; W. Chrostowski, [rev.:] Mowy przeciw arianom I-III, Atanazy Wielki, przeł., red. Przemysław Marek Szewczyk, Kraków 2013 - CT 83.2, 2013, p. 230.

${ }^{13}$ Cf. D. Brakke, Athanasius and the Politics of Asceticism, Oxford 1995, p. 23-30; E. Wipszycka, L'Ascetisme féminin dans l'Égypte de l'Antiquité Tardive: Topoi littéraires et formes d'ascese, [in:] Le Rôle et le statut de la femme en Egypte hellénistique, romaine et byzantine. Actes du colloque international 27-29 novembre 1997, ed. H. Melaerts, L. Mooren, Paris 2002, p. 355-396.

${ }^{14}$ E. WipszycKa, Wprowadzenie do studiów nad instytucjami Kościoła w Egipcie późnoantycznym, [in:] Chrześcijaństwo u schyłku starożytności. Studia Źródłoznawcze, vol. II, ed. T. Derda, E. WipSZYCKA, Kraków 1999, p. 209-210.

${ }^{15}$ In the preserved fragments of Sahidian manuscripts of The Canons of Athanasius, which are the oldest copy of the work, there is no introduction or ending. Therefore, we do not know whether there was an annotation concerning the authorship of Athanasius there, cf. E. Wipszycka, The Alexandrian Church..., p. 30.

${ }^{16}$ Cf. A. Martin, Athanase d'Alexandrie..., p. 657; E. Wipszycka, Wprowadzenie do studiów..., p. 209. ${ }^{17}$ This is supported by the information in individual canons. The author writes about a bathhouse (canon 31, p. 31), a theatre (canon 75, p. 48), and brothels (canon 93, p. 60). In the case of Egypt, any city other than Alexandria could be considered provincial. Cities in Egypt were already large centers of population in the Ptolemy era. Some of them even had from a dozen to several tens of thousands of inhabitants. On the population, organization and infrastructure of Egyptian cities, cf. R.S. BAGNALL, Egypt in Late Antiquity, Princeton 1993, p. 45-109; A. ŁukAszewicz, Egipt Greków i Rzymian, Warszawa 2006, p. 382-410; P. van Minnen, The Rother Cities in Later Roman Egypt, [in:] Egypt in the Byzantine World 300-700, ed. R.S. BAGNALL, Cambridge 2007, p. 207-225.
} 
a great deal of freedom in managing his parishes. Perhaps the expression of his ambition was to create this collection of canons.

The Canons of Pseudo-Athanasius is undoubtedly a very important source on the history of early Christianity. It provides significant amount of information, describing the realities of the world in which Christians lived at the end of the fourth and at the beginning of the fifth century in Egypt. It is a very original collection of guidelines, as the author did not use any earlier sets of church standards to create it. He did not use the model of standards found in the Apostolic Tradition, as was often the case with other founders of ecclesiastical laws. It is possible that he wrote from his own experience ${ }^{18}$.

According to him, the bishop played a significant role in the community of the city and his activity was not limited to the spiritual sphere. It also included due care for the finances of the local Church, as they were the means, among other things, to provide for all the disadvantaged. The Canons of the Pseudo-Athanasius offers a new perspective on the social order. The author devoted significant attention to the group that until then had been pushed to the margins of every urban community. This group included people without any prospects, that is to say, the poor $^{19}$. Perhaps the strong emphasis on their needs was due to the fact that the community neglected them and did not provide them with the necessary alms. It may be for this reason that the author decided that he should support his guidelines with the authority of the great Bishop Athanasius. Undoubtedly, it is certain that the author had a concrete idea of the daily life of the Christian community. The canons he left shed a lot of light on how he thought it should look.

\section{The image of the work of the Church steward}

The Canons of Pseudo-Athanasius devotes a great deal of attention to the work of the administrator of the ecclesiastical estate, namely the steward. His responsibilities were very important from the point of view of the bishop, who supervised charity activities, supported orphans, widows, consecrated virgins and the poor. He also sometimes provided means for local priests and was involved in the renovation or extension of churches ${ }^{20}$. In this source we can find as many

\footnotetext{
${ }^{18}$ This assumption was made by Ewa Wipszycka (The Alexandrian Church..., p. 31) and is not unfounded. The author touches upon many interesting but also specific problems, which reveal his personal observations. For example, he writes about the fact that clerics should not talk and look at the faces of their companions during a meal (canon 67, p. 43). He also prohibits deacons from playing, making jokes or telling vain things when they are at the altar during the service (canon 27, p. 31). Of course, this ban seems bizarre to us today, but given the fact that services then lasted several hours and that deacons were usually young men, it is highly likely that such situations could have occurred. ${ }^{19}$ A. Martin, 'L'image de l'évêque à travers les Canons d'Athanase: devoirs et réalités, [in:] L'évêque dans la cité $d u I V^{e}$ au Ve siecle. Image et l'autorité, ed. E. Rebillard, C. Sotinel, Rome 1998, p. 60. ${ }^{20}$ Cf. Can. Ps. Athan., 65, p. 42, 43.
} 
as five extensive fragments that contain guidelines for stewards. In addition, the author discussed the competences of episcopal church stewards (whom I call diocesan for convenience sake) and parish stewards.

First of all, let us look at the criteria that the author set for the candidates for this position. Canon 61 tells us that such a candidate was supposed to be a man of compassion, capable, if necessary, of ignoring the status of the person in need of his assistance and avoiding people of dishonest and greedy character. He was also meant to show fatherly care for widows and orphans. The author also expected that the steward would work closely with the bishop and that they would not make any decision regarding financial matters unless they were both in agreement ${ }^{21}$. It is interesting to note that The Canons of Pseudo-Athanasius outlined the criteria to be met by candidates for this post and set a deadline for their appointment, but did not describe the selection procedure itself. Perhaps Pseudo-Athanasius believed that everyone was familiar with it and that there was no need to discuss it. In this respect, it should be noted that other sources also do not discuss in any detail the procedures related to nominating the steward ${ }^{22}$.

In canon 62, the author stated that Easter would be a fixed date for the nomination of all stewards ${ }^{23}$. In the Coptic version, the terms "steward" and "church" were used in plural ${ }^{24}$. Based on this, Oxford scholar Amin Benaissa concluded that this prerogative applied not only to the communities of the city in which the writer resided, but also to all the parishes in the diocese $\mathrm{e}^{25}$. We must note that

${ }^{21}$ Can. Ps. Athan., 61, p. 40, 41.

${ }^{22}$ Canon 10 of Theophilus, Metropolitan Bishop of Alexandria (Theophile D'Alexandrie, [in:] P.-P. JoAnnou, Discipline générale antique (IVe-IXe s.). Les canons des Pères Grecs, vol. II, Roma 1963, p. 270) tells us only in Egypt, the steward could be elected by the local clergy and his candidacy had to be confirmed by the bishop. Most often, it was a clergyman who was appointed a steward. However, papyrus documents shed more light on who assumed this role in rural parishes. It follows that this was not always someone from the clergy. The reason may have been the lack of appropriate competences; cf. A. BEnAIssa, A Bishop, a Village, and the Nomination of a Church Steward, ZPE 171,2009 , p. 175. This function was sometimes performed by representatives of the local aristocracy, which seems understandable given that they were probably among the most generous donors of the Church. With their large assets and good education, they probably wanted to maintain their influence on the management of church funds of the local community; cf. E. WiPszYcKA, Les ressources et les activités économiques des églises en Égypte du IVe au VIII siècle, Bruxelles 1972, p. 148, 149. Of course, the appointment was always approved by the bishop. There is also a letter that certifies that the administrator was selected by the community. Amin Benaissa (A Bishop, a Village, and the Nomination..., p. 175, 176) suspects that this may have been the result of a lack of consensus among the clergy, which is why the bishop transferred the right to choose the steward to the faithful, thus creating a sense of collective responsibility for the proper supervision of Church finances.

${ }^{23}$ Can. Ps. Athan., 62, p. 41.

${ }^{24}$ This understanding is confirmed by the Coptic version of Canon 62, which uses the term NOIKONOMOC "steward" in plural, cf. Coptic Text the Canons of Athanasius of Alexandria, trans. W.E. Crum, [in:] The Canons of Athanasius... (cetera: Copt. Can. Ps. Athan.), p. 100, 129.

${ }^{25}$ A. Benaissa, A Bishop, a Village, and the Nomination..., p. 176. 
the researcher treated the information from canon 62 of Pseudo-Athanasius as fully reliable. Meanwhile, it should be pointed out that we do not know of any other document that would confirm that the appointment of stewards occurred during Easter. I therefore believe that this particular provision of Pseudo-Athanasius must be approached with caution. Presumably, the appointment of stewards could have taken place at that time, but we must not forget that it was our canonist's ambition that the norms he wrote should apply to the whole Church. The question therefore arises as to why he chose Easter to carry out these nominations. It seems that the answer can be found in canon 16, in which PseudoAthanasius recommended that the poor and the needy be given special gifts on that occasion ${ }^{26}$. As it was the administrators who were responsible for providing them with the necessary resources, he might have considered that their appointment during the Easter celebrations would highlight the role they played in this charitable activity.

Pseudo-Athanasius precisely defined the scope of supervision over church finances for stewards. Canon 61 offers information that the diocesan steward managed all ecclesiastical property, including the reserves of grain, fruit and seeds. However, he had to be approved by the bishop to carry out major financial operations and, in so doing, he was to keep himself strictly at his disposal. The basic unit of measurement for bulk products, for the distribution of which the steward required a permit from the bishop, was one $a r t a b a^{27}$. As long as the expenditure was less than one artaba, the steward was able to dispose of funds more freely in order to help the poor $^{28}$. Nevertheless, he still had to account to the bishop for the costs incurred. Parish stewards managed all the church property of the local community. However, canon 81 clearly indicates that if they needed funds for some additional expenses, then they had to go to the bishop and to the diocesan steward ${ }^{29}$. Canon 62 tells us that stewards were also responsible for the storage of liturgical vessels ${ }^{30}$. Once a year, the diocesan steward was to

${ }^{26}$ Cf. Can. Ps. Athan., 16, p. 26-28.

${ }^{27}$ In Arabic one $\operatorname{ardeb}$ (Gr. $\alpha \rho \tau \alpha \beta \eta$ ). It is a unit of capacity for bulk products, already used in ancient Egypt. According to sources, in Roman times one artab usually amounted to about 40 liters. However, in some cases it ranged from 29 to 46 liters; cf. A Patristic Greek Lexicon, ed. G.W.H. LAMPE,

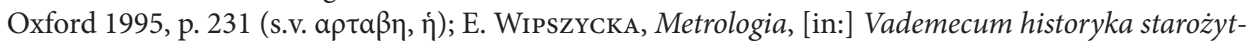
nej Grecji i Rzymu, vol. I-II, ed. E. WipszyckA, Warszawa 2001, p. 581; A. ŁukAszeWicz, Egipt Greków..., p. 553. During the research, scholars would prefer to use relatively precise units of capacity and weight. Therefore, for many years they have been trying to determine, which units and in what proportion constituted one artab, and which other units it corresponded to. This task is all the more difficult as documents from different periods give its different values, cf. D.W. Rathbone, Weight

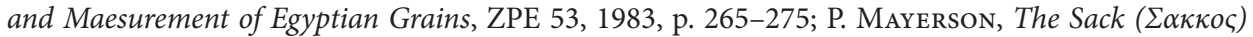
Is the Artaba Writ Large, ZPE 122, 1998, p. 189-194.

${ }^{28}$ Can. Ps. Athan., 61, p. 40, 41. Cf. E. WipszyckA, Les ressources..., p. 138, 139.

${ }^{29}$ Can. Ps. Athan., 81, p. 50.

${ }^{30}$ Can. Ps. Athan., 62, p. 41. 
make an inventory of them in order to make sure that nothing was lost. The date set by Pseudo-Athanasius for the audit was Easter ${ }^{31}$.

According to the author of The Canons of the Pseudo-Athanasius, one of the basic duties of stewards was to support the needy. In canon 61, he included orphans, widows and the poor among them ${ }^{32}$. In canons 80 and 81 , he referred to the needs of the lonely, the sick and the wanderers ${ }^{33}$. The author emphasized that if sick people appeared in the church xenodochium: who had the necessary means to live, then they could not be a burden for the Church ${ }^{34}$. It probably meant people whose material status or close relatives ensured them livelihood. However, those who were poor and had no place to go had to be taken care of by the steward. He should then provide them with a place in a dormitory near the church and supply them with the necessary food and medicine. Pseudo-Athanasius encouraged administrators to extend particular care for their guests as well. Most probably, he was concerned about itinerant monks or pilgrims. If the parish steward

${ }^{31}$ Can. Ps. Athan., 61, 62, p. 41. Ewa Wipszycka (Church Treasures of Byzantine Egypt, JJP 34, 2004, p. 130) explains that the so-called "minor" stewards mentioned in the canon are men who administered the property of churches in which there was no regular worship because they were dedicated to selected saints. They were opened on holidays in accordance with the schedule set by the bishop. Therefore, because of the risk of theft, liturgical vessels were not kept in them permanently. The stewards kept the liturgical vessels in special hiding places, from which they took them out if needed. The scholar quoted the following story (p. 128, 129), which shows that only the administrator knew the hiding place and that in the event of his death there was a risk of losing those vessels. Of course, such situations may have occurred, but I do not think they were the rule. We must remember that the entire property of the diocese was administered by the bishop. Canon 89 , discussed below, shows how precise the mechanism for securing church treasuries in the diocese's seat was. Besides, it seems unlikely that bishops in an era plagued by persecution, controversy and heresies would allow stewards so much autonomy. I suspect that apart from the so-called "minor" steward, the location of the hiding place must have been known by the bishop or the diocesan steward. According to canon 62, the bishop was to be informed verbally by the stewards of the current stock of liturgical vessels owned by the community, and he was to record it. Cf. Can. Ps. Athan., 62, p. 41. Of course, the bishop did not carry out such inventory in person. This is confirmed by the Coptic version of this provision, which states that the administrators would present the number of liturgical vessels to the diocesan steward, who, after writing it down, was to inform the bishop about everything; cf. Copt. Can. Ps. Athan., 62, p. 129.

${ }^{32}$ Can. Ps. Athan., 61, p. 40.

${ }^{33}$ Can. Ps. Athan., 80, 81, p. 50. We must consider both provisions together, as they were originally an integral part of the text.

${ }^{34}$ This is the meaning of the Arabic text of the first sentence of canon 80, which Wilhelm Riedel correctly conveyed in his translation; cf. Can. Ps. Athan., 80, p. 49. In the East, institutions where the sick were cared for, but most of all travellers and pilgrims, were xenodochia. Some of them were church dormitories, others were established next to monasteries, and others still were established thanks to private foundations along the pilgrimage routes; cf. J.E. CANAVAn, Charity in the Early Church, S.IQR 12, 1923, p. 73, 74; S. Longosz, Ksenodochium - hospicjum wczesnochrześcijańskie, VP 16, 1996, p. 275-336; M. Voltaggio, Xenodochia and Hospitia in Sixth-Century Jerusalem: Indicators for the Byzantine Pilgrimage to the Holy Places, ZDPV 127, 2011, p. 197-210. 
lacked funds for this purpose, he was to turn to the bishop or diocesan steward for help. Most likely he would have to apply for the needed means to the diocesan steward, who in turn asked the bishop for approval ${ }^{35}$. It is worth noting that the author thus recommended practicing Christian hospitality ${ }^{36}$.

Fraudulence on the part of many stewards of that time must have posed a significant problem. The author devoted a lot of attention to this issue. Based on the first line of canon 89 we can deduce that there were diocesan stewards who stole from the church treasury ${ }^{37}$. In canon 90, continuing this theme, Pseudo-Athanasius quoted two negative examples from the Bible, which were meant to serve as a warning to the administrators ${ }^{38}$. One concerned Judas, who stole the common money from the apostles, and the other referred to Prince Balthazar, who ruled in Chaldea on behalf of his father Nabonidus and used dishes stolen from the Temple of Jerusalem during the feast. The author implied that both of them lost their lives because they had taken someone else's property ${ }^{39}$. At the end, he shared a memory of a miracle that was supposed to have happened in his youth. He spoke of a thief who had crept into a church to steal liturgical vessels, but who could not leave because Divine Providence stopped him and thus he fell into the hands of the $\mathrm{law}^{40}$. The tone of the whole fragment was unambiguous. If the steward were to steal or cheat, he would be severely punished. It is interesting, however, that the author did not specify on that occasion what consequences such an offender was meant to face in accordance with the ecclesiastical law. Only in canon $61 \mathrm{did}$

\footnotetext{
${ }^{35}$ Can. Ps. Athan., 80, 81, p. 49, 50. Cf. E. Wipszycka, Les ressources..., p. 136, 137. According to the guidelines of canon 61 already discussed, the diocesan steward had to ask the bishop for permission to make the payment if its value exceeded 1 artaba.

${ }^{36}$ Hospitality in the East was a custom already practiced in Biblical times. It was the host's duty not only to feed the guest, but also to clothe him, provide accommodation for the night and equipment for the rest of the journey. Christians also cultivated this custom, although their preferred hospitality was limited to their faithful relatives and travellers, as well as to pilgrims and itinerant monks. According to the Church's prohibitions, it should not include pagans, schismatics, and heretics, cf. H. Wójtowicz, Gościnność wczesnochrześcijańska, VP 16, 1996, p. 229-239. John Chrysostom devoted much attention to the topic of hospitality in his homilies, cf. IoAnnes Chrisostomus, In Epistulam ad Romanos, hom. 21, 4, 5; 30, 4, [in:] PG, vol. LX, col. 606, 607, 666.

${ }^{37}$ Can. Ps. Athan., 89, p. 55.

${ }^{38}$ Can. Ps. Athan., 90, p. 57.

${ }^{39}$ In order to support his arguments, the author treated both Biblical accounts quite instrumentally. Judas and Balthazar were not killed as a result of their own fraud. Judas committed suicide after having betrayed Jesus, while Balthazar did not steal these temple vessels because Nebuchadnezzar II had done so many years earlier. According to the author of The Book of Daniel, Baltazar's death was caused by the sacrilegious use of these vessels. The Chaldean ruler died as a result of the invasion of Babylon by Cyrus II of Persia, which is not mentioned in the cited Biblical story; cf. Mt 27, 3-5; Dn $5,1-30$. On the circumstances of the Persian invasion of Babylon cf. M. van De Mieroop, A History of the Ancient Near East ca. 3000-323 BC, ${ }^{2}$ Oxford 2007, p. 279-285.

${ }^{40}$ Can. Ps. Athan., 90, p. 57, 58.
} 
he mention that such a steward should be stripped of his function ${ }^{41}$. It seems that from his point of view the worst consequence was God's own dissatisfaction in that case $\mathrm{c}^{42}$.

Despite his trust in God's justice, our author had limited trust in people. That is why he developed procedures to prevent the misuse of funds that belonged to the Church. He presented them in canon $89^{43}$. The provision states clearly that the diocesan steward received funds from all the parishes. It meant money, valuables, expensive fabrics, but also gifts in kind, including grain, vegetables and fruit and olive oil ${ }^{44}$. For this reason, Pseudo-Athanasius ordered that the gates of treasuries and church warehouses should bear three seals: one of the bishop, one of the archpriest and one of the steward ${ }^{45}$. He stipulated that these rooms could only be opened in the presence of all three of them ${ }^{46}$. He then proposed that a financial reserve be set in the treasury to be used in emergency situations (such as crop

${ }^{41}$ Cf. Can. Ps. Athan., 61, p. 41.

${ }^{42}$ Cf. Can. Ps. Athan., 9, p. 18.

${ }^{43}$ Can. Ps. Athan., 89, p. 55. Papyrus documents suggest that sometimes stewards had really large sums of money and significant resources in kind at their disposal, as they certify that many types of financial operations were being carried out. Among other things, administrators paid salaries to those hired by the Church to do various jobs, acted as agents in the finalization of lease and sale agreements and paid taxes on the real estate owned by the Church, cf. E. WipszycKa, Les ressources..., p. 139, 140.

${ }^{44}$ Ibidem, p. 139.

${ }^{45}$ The custom of securing clo sed rooms and documents with seals was born and quickly spread throughout the Middle East. In Mesopotamia, the so-called cylindrical seals were known. In Egypt, pharaoh tombs and granaries were sealed.

${ }^{46}$ Ewa Wipszycka (Les ressources..., p. 138) noted that the mechanisms for mutual control of integrity between the bishop and the steward proved inadequate. According to the author of The Canons of Pseudo-Athanasius (89, p. 55), the wealth and expenses of the church treasury were to be supervised additionally by the archpriest. Such a need seems to be confirmed by the story I have mentioned earlier about Presbyter Isidore, who was a steward of the Bishop of Alexandria, Theophilus. Hermias Sozomen (Sozomène, Histoire Ecclésiastique, VIII, 12, trans. A.-J. Festugière, B. Grillet, Paris 2008 [= SC, 516], p. 286, 287) explains that one of the reasons for the conflict between the two clergymen was that Theophilus intended to appropriate a certain amount from the funds offered for the needs of the poor and the sick. This was explained by the expenses he had incurred on the construction of churches. Isidore did not agree, however, because he believed that the needs of the poor and the sick were more important than building new temples. This account therefore demonstrates that some bishops may have gotten unfairly rich by exerting pressure on stewards to misappropriate the funds entrusted to them. Counteracting dishonesty and corruption in church structures was not, and is not, an easy task. The rules show that the control measures implemented were most likely to fail. If a bishop who had judicial powers and appointed subordinate hierarchs was corrupt, it is hard to imagine that the rest of the clergy could successfully oppose him. In addition, we must note that the mention of the function of the archpriest confirms how complex the hierarchy of the structures of the Egyptian Church was. More on the subject cf. E. WipszycKA, The Alexandrian Church..., p. 246, 331-333. 
failure, major fire, epidemic ${ }^{47}$. He stressed, however, that such savings should not be made at the cost of reduction of the amount of alms paid to the poor.

The author of The Canons of Pseudo-Athanasius was a supporter of centralist management of church funds. He allowed stewards little autonomy in that area and left all more serious decisions to the bishops ${ }^{48}$. He devoted a great deal of attention to the responsibilities of administrators, pointing to their important role in the Church's charitable activities. The Canons of Pseudo-Athanasius is one of the sources providing the most information on the work of stewards in the late Antiquity era. Although the author described this function from a local perspective, he had the ambition that his guidelines should apply throughout the Egyptian Church. The office of steward had been known in Egypt since the Pharaohs, and the Church there was the first to establish this function within the diocese. In the East, the practice of appointing stewards spread rapidly. This was mentioned by Basil the Great ${ }^{49}$. However, the canon of the $26^{\text {th }}$ Council of Chalcedon (451) stated that in some dioceses there was no such office, which, according to the Council fathers, contributed to the waste of property. That is why they called for the appointment of a steward in every diocese. Previously, it had not been mandatory to employ administrators ${ }^{50}$.

Translated by Katarzyna Gucio

\footnotetext{
${ }^{47}$ In my opinion, this fragment of canon 89 does not contradict the content of canon 82 (Can. Ps. Athan., 82, p. 50), which prohibits clergy from accumulating stocks of tithes and original harvests. I suppose that canon 82 concerns agricultural products that easily deteriorated or fell prey to pests, so it was very risky to store them for a long time. Probably canon 82 was also meant to counteract the unjust enrichment of priests, who, through under-measuring, deceived the needy. Later on, they could easily make extra profits from the sale of agricultural products, which were, after all, bare necessities. Meanwhile, Pseudo-Athanasius in canon 89 mentions the accumulation of money left after paying the alms. Of course, a clergyman's attempt to get rich by stealing from church treasury could quickly be exposed. However, as I have written above, canons 89 and 90 clearly indicate that this procedure must have taken place frequently, too.

${ }^{48}$ Cf. E. Wipszycka, Les ressources..., p. 132.

${ }^{49}$ Cf. Basilius Caesariensis, Epistula CL, [in:] Saint Basil, Letters 59-185, trans. R.J. Deferrari, Cambridge Mass.-London 1928 [= LCL, 215], p. 368, 369.

${ }^{50}$ Cf. Concilium Chalcedonense - 451, can. 26, [in:] COGD, vol. I, ed. G. Alberigo, Turnhout 2006, p. 149.
} 


\section{Bibliography}

\section{Primary Sources}

Basilius Caesariensis, Epistula CL, [in:] Saint Basil, Letters 59-185, trans. R.J. Deferrari, Cambridge Mass.-London 1928 [= Loeb Classical Library, 215].

Les Canons de Saint Athanase, [in:] H. Munier, Mélanges de litterature copte, "Annales du Service des antiquités de l'Egypte" 19, 1920, p. 238-241.

The Canons of Athanasius of Alexandria, ed. W. Riedel, W. Crum, London 1904.

Concilium Chalcedonense - 451, [in:] Conciliorum Oecumenicorum Generaliumque Decreta, vol. I, ed. G. Alberigo, Turnhout 2006, p. 125-151.

Coptic Text the Canons of Athanasius of Alexandria, trans. W.E. Crum, [in:] The Canons of Athanasius of Alexandria, ed. W. Riedel, W. CRUM, London 1904.

IoAnnes Chrisostomus, In Epistulam ad Romanos, [in:] Patrologiae cursus completus, Series graeca, vol. LX, ed. J.-P. Migne, Paris 1862, col. 385-682.

Sozomène, Histoire Ecclésiastique, vol. IV, trans. A.-J. Festugière, B. Grillet, Paris 2008 [= Sources chrétiennes, 516].

Theophile d'Alexandrie, [in:] P.-P. Joannou, Discipline générale antique (IVe-IXee s.). Les canons des Pères Grecs, vol. II, Roma 1963, p. 259-273.

\section{Secondary Literature}

Anatolios K., Athanasius. The Coherence of His Thought, London-New York 2004, https://doi.org/ $10.4324 / 9780203008904$

Bagnall R.S., Egypt in Late Antiquity, Princeton 1993.

Benaissa A., A Bishop, a Village, and the Nomination of a Church Steward, "Zeitschrift für Papyrologie und Epigraphik" 171, 2009, p. 175-180.

Brakke D., Athanasius and the Politics of Asceticism, Oxford 1995.

Brakke D., Canon Formation and Social Conflict in Fourth-Century Egypt: Athanasius of Alexandria's Thirty-Ninth Festal Letter, "The Harvard Theological Review" 87.4, 1994, p. 395-419, https://doi.org/10.1017/S0017816000030200

Canavan J.E., Charity in the Early Church, "Studies: An Irish Quarterly Review" 12, 1923, p. 61-77.

Chrostowski W., [rev.:] Mowy przeciw arianom I-III, Atanazy Wielki, przeł., red. Przemysław Marek Szewczyk, Kraków 2013 - "Collectanea Theologica" 83.2, 2013, p. 228-231.

Coquin R.G., Canons of Pseudo-Athanasius, [in:] The Coptic Encyclopedia, vol. II, ed. A.S. AtryA, New York 1991, p. 458-459.

De Mieroop M. van, A History of the Ancient Near East ca. 3000-323 BC, ${ }^{2}$ Oxford 2007.

HejJer J. DEN, History of the Patriarchs of Alexandria, [in:] The Coptic Encyclopedia, vol. IV, ed. A.S. AtiYa, New York 1991, p. 1239-1242.

Longosz S., Ksenodochium - hospicjum wczesnochrześcijańskie, "Vox Patrum. Antyk Chrześcijański” 16, 1996, p. 275-336.

Łukaszewicz A., Egipt Greków i Rzymian, Warszawa 2006.

Martin A., Athanase d'Alexandrie et l'Église d'Égypte au IV siecle (328-373), Rome 1996. 
Martin A., 'L'image de l'évêque à travers les Canons d'Athanase: devoirs et réalités, [in:] L'évêque dans la cité du IV au V' siecle. Image et l'autorité, ed. E. Rebillard, C. Sotinel, Rome 1998, p. 59-70.

Mayerson P., The Sack ( $\Sigma \alpha \kappa \kappa o \varsigma)$ Is the Artaba Writ Large, "Zeitschrift für Papyrologie und Epigraphik" 122, 1998, p. 189-194.

Minnen P. van, The Rother Cities in Later Roman Egypt, [in:] Egypt in the Byzantine World 300-700, ed. R.S. Bagnall, Cambridge 2007, p. 207-225.

Munier H., Mélanges de litterature copte, "Annales du Service des antiquités de l'Egypte" 19, 1920, p. 225-241.

A Patristic Greek Lexicon, ed. G.W.H. Lampe, Oxford 1995.

Rathbone D.W., Weight and Maesurement of Egyptian Grains, "Zeitschrift für Papyrologie und Epigraphik" 53, 1983, p. 265-275.

Renaudot E., Historia Patriarchum Alexandrinorum Jacobitarum ad Marco usque ad finem saeculi XIII, Paris 1713.

Riedel W., Introduction, [in:] The Canons of Athanasius of Alexandria, ed. W. Riedel, W. Crum, London 1904, p. VII-XXX.

Schmidtz D., Schimpfwörter in Athanasius' Rede gegen die Arianer, [in:] Roma Renascens. Beiträge zur Spätantike und Rezeptionsgeschichte - Ilona Opelt von Ihren Freunden und Schülern zum 9.7.1988 in Verehrung gewidmet, ed. M. WissemanN, Frankfurt-Paris 1988, p. 308-320.

Stewart R., Tinnis, [in:] The Coptic Encyclopedia, vol. VII, ed. A.S. Atiya, New York 1991, p. 2269.

Suciu A., Notes on the Canons of Pseudo-Athanasius, https://alinsuciu.com/2011/07/02/notes-onthe-canons-of-pseudo-athanasius/

Voltaggio M., Xenodochia and Hospitia in Sixth-Century Jerusalem: Indicators for the Byzantine Pilgrimage to the Holy Places, "Zeitschrift des Deutschen Palästina-Vereins" 127, 2011, p. 197-210.

WipszycKa E., The Alexandrian Church. People and Institutions, Warsaw 2015 [= The Journal of Juristic Papyrology. Supplement, 25].

Wipszycka E., L'Ascetisme féminin dans l'Égypte de l'Antiquité Tardive: Topoi littéraires et formes d'ascese, [in:] Le Rôle et le statut de la femme en Egypte hellénistique, romaine et byzantine. Actes du colloque international 27-29 novembre 1997, ed. H. Melaerts, L. Mooren, Paris 2002, p. 355-396.

Wipszycka E., Church Treasures of Byzantine Egypt, "The Journal of Juristic Papyrology" 34, 2004, p. 127-139.

Wipszycka E., Études sur le Christianisme dans l'Egypte de l'antiquite tardive, Roma 1996 [= Studia Ephemeridis Augustinianum, 52].

WipszycKa E., Le Istituzioni Ecclesiastiche in Egitto, [in:] L'Egitto Cristiano aspetti e problemi in eta Tardo-Antica, ed. A. Camplani, Roma 1997 [= Studia Ephemeridis Augustinianum, 56], p. 219-271.

Wipszycka E., Metrologia, [in:] Vademecum historyka starożytnej Grecji i Rzymu, vol. I-II, ed. E. WIPSZYCKA, Warszawa 2001, p. 573-585.

Wipszycka E., Les ressources et les activités économiques des églises en Égypte du IV au VIII siècle, Bruxelles 1972.

WipszycKa E., Wprowadzenie do studiów nad instytucjami Kościoła w Egipcie późnoantycznym, [in:] Chrześcijaństwo u schyłku starożytności. Studia źródłoznawcze, vol. II, ed. T. DerdA, E. WIPSzYCKA, Kraków 1999, p. 183-261.

Wójtowicz H., Gościnność wczesnochrześcijańska, "Vox Patrum. Antyk Chrześcijański” 16, 1996, p. 229-239. 


\begin{abstract}
The office of a steward was known in Egypt back in the time of the Pharaohs. It appears that in the East, this function first emerged in the structures of the Egyptian Church. The Canons of Pseudo-Athanasius, which probably come from the first half of the $5^{\text {th }}$ century, show the author's views on how the church stewards fulfilled their duties. Pseudo-Athanasius not only outlined the criteria to be met by these administrators, but also indicated the date by which, in his opinion, they should be solemnly appointed. In addition, this source informs us how these church administrators were supposed to fulfill their obligation to collect and secure church property for the Church's charitable activities. The author emphasized that the steward played a key role in how efficiently actions in support of the poor were implemented, however, he also observed that these tasks were fully dependent on the will of the local bishop. Pseudo-Athanasius also devoted considerable attention to the important problem of the dishonesty of some administrators. Therefore, he postulated that the vaults and granaries should be secured with seals by a commission and that they be opened in the same way. The author had an interesting idea to create a reserve in the treasury, which, in the event of a cataclysm or other calamity, would provide food for the community. Undoubtedly, the Canons of Pseudo-Athanasius are an extremely valuable source that deepens our knowledge about the work of church stewards at that time. There are numerous indications that the author included his own observations in them. However, it should be remembered that the description of the steward's duties presented here is a model proposition, therefore, in order to obtain a more complete picture, it should be confronted with other sources from the era.
\end{abstract}

Keywords: Canons of Pseudo-Athanasius, Egyptian Christianity, Church steward, management of ecclesiastical property, charity activities, artaba, xenodochium, Church treasure

Andrzej R. Hołasek

Waldemar Ceran Research Centre for the History and Culture of the Mediterranean Area and South-East Europe

ul. Matejki 32/38, sala 319

90-237 Łódź, Polska/Poland a.holasek@onet.eu 